Buca Eğitim Fakültesi Dergisi, 2021, say1 52, s. 168-184

Araştırma Makalesi
The Journal of Buca Faculty of

Education, 2021, issue 52, p. 168-184

Research Article

\title{
Hayat Bilgisi Dersi Temel Yaşam Becerileri ve Kazanımlarının Öğretmen Görüsşlerine Göre Değerlendirilmesi*
}

\section{Evaluation of Life Study Course Basic Life Skills and Objectives According to Teacher's Opinions}

\author{
Gülsüm YILDIRIM ${ }^{1}$
}

\begin{abstract}
${ }^{1}$ Sorumlu Yazar, Dr. Öğretim Üyesi, Temel Ĕ̆itim Bölümü, Ĕ̆itim Fakültesi, Hakkari Üniversitesi, Türkiye, yildirimgulsum27@hakkari.edu.tr, (https://orcid.org/0000-0003-29874775)
\end{abstract}

Geliş Tarihi: 04.02.2021

Kabul Tarihi: 08.10.2021

ÖZ

$\mathrm{Bu}$ araştırmanın amacı, 2018 hayat bilgisi öğretim programındaki temel yaşam becerilerinin kazanımlara göre dağılımını ve 2018-2019 öğretim yılında uygulanan hayat bilgisi öğretim programı kazanımlarının amacına ulaşma düzeyini sınıf öğretmenlerinin görüşlerine göre belirlemektir. Araştırmada 2018 hayat bilgisi öğretim programındaki temel yaşam becerilerinin kazanımlara göre dağılımını belirlemek için doküman taraması yapılmış; kazanımların öğretmen görüşlerine göre değerlendirilebilmesi için de tarama yöntemi kullanılmıştır. Veriler, internet üzerinden gönderilen anketler yoluyla 294 öğretmenin katılımıyla toplanmıştır. Temel yaşam becerileri ve kazanım dağılımları nitel analiz yöntemlerinden betimsel analiz, anketlerle toplanan veriler de betimsel istatistiklerle analiz edilmiştir. Araştırma sonucunda 2018 hayat bilgisi öğretim programındaki 148 kazanımdan 126'sının temel beceriler ile uyumlu olduğu; ancak 22 kazanımın programda belirtilen temel yaşam becerileri ile uyumlu olmadığı sonucuna ulaşılmıştır. Bununla birlikte 126 kazanımın ise temel yaşam becerilerine eşit dağılmadığı belirlenmiştir. Ayrıca bazı beceriler sadece bir sınıf düzeyinde yer alırken bazı beceriler yalnızca iki ayrı sınıf düzeyinde yer almaktadır. Bununla birlikte sınıf öğretmenlerine göre kazanımlar bir, iki ve üçüncü sınıf düzeylerinde genel olarak orta düzeyde kazandırılmaktadır. Bu kapsamda ilkokul çocuğunun gelişimini destekleyecek temel yaşam becerileri için hazırlanan kazanımlar her sınıf düzeyinde eşit olarak yer almalı ve bunları yüksek düzeyde kazandıracak koşullar oluşturulmalıdır.

Anahtar Kelimeler: İlkokul, sınıf öğretmeni, hayat bilgisi öğretim programı, temel yaşam becerileri.

\begin{abstract}
The aim of this research is to determine the distribution of basic life skills in the 2018 life studies curriculum (LSC) according to the objectives and the level of reaching the goals of the LSC curriculum implemented in the 2018-2019 academic year, according to the opinions of the classroom teachers. In the research, document analysis method was used to determine the distribution of basic life skills in the 2018 LSC according to the objectives. Survey method was also used to evaluate the objectives according to the teachers' opinions. The data were collected through online questionnaires with the participation of 294 teachers. In the analysis of the research data, while basic life skills and objectives distributions were examined with descriptive analysis, descriptive statistics were used for the questionnaires. As a result of the research, it was concluded that 126 of the 148 objectives in the 2018 LSC were compatible with basic skills, but 22 of them were not compatible with the basic life skills specified in the program. However, it
\end{abstract}

\footnotetext{
* Bu araştırma Prof. Dr. Naciye AKSOY danışmanlığında hazırlanan "İlkokul Düzeyinde Öğrencilere Kazandırılması Gerekli Temel Yaşam Becerilerinin Hayat Bilgisi Dersi Bağlamında Analizi” doktora tezinden üretilmiştir.
} 
was determined that 126 objectives are not equally distributed to basic life skills. In addition, some skills are located at only one grade level, while some skills are only at two separate grade levels. However, according to classroom teachers, the objectives are generally at a medium level at the first, second and third grade levels. In order to support the completion of this education training, the achievements for basic education should be high at every grade level and the conditions for training them should be created.

Keywords: Primary school, classroom teachers, life study curriculum, basic life skills.

\section{GíRiș}

Yirmi birinci yüzyılda bir yandan insan hayatını kolaylaştıran hızlı teknolojik ilerlemelere ve buna bağl1 toplumsal dönüşümlere; diğer yandan da küresel 1sınma, işsizlik, savaşlar, çatışmalar, su krizleri, açlık gibi yerel ve küresel sorunlara tanıklık edilmektedir. Hem bu dönüşümlere hızlı bir şekilde uyum sağlayacak hem de yerelde ve küresel düzeyde karşılaştığ1 sorunlarla etkili bir şekilde mücadele edecek ve çözüm üretecek bireylere duyulan ihtiyaç her geçen gün artmaktadır. Bu ihtiyaç kapsamında eğitim programlarında da değişimler gerçekleştirilmektedir. Değişim yapılan programlardan birisi de zorunlu eğitimin ilk basamağ olan ilkokulun ilk üç yılında okutulan hayat bilgisi öğretim programıdır.

Sosyal bilimler ve doğa bilimlerinden temelini alan hayat bilgisi, öğrencilerin daha etkin bireyler ve vatandaşlar olarak yaşam sürmelerine zemin hazırlayan ve ikinci devre derslerine temel oluşturan çocuk gelişimine uygun bir öğretim programı olarak tanımlanmaktadır (Baysal, 2006, s. 3). Hayat bilgisi; küçük yaşlardan itibaren çocuğun toplumsal ve kültürel çevreyi incelemesini sağlayan, doğa ve çevre sorunlarıyla ilgili doğru ve sağlam bilgiler edinerek çevreye uyum için gerekli iyi alışkanlık ve beceriler öğretmeyi amaçlayan bir ders olarak da açıklanmaktadır (Binbaşığlu, 2003, s. 11). Milli Eğitim Bakanlığı (MEB, 2005) çocuğun gelişim özellikleri göz önüne alınarak toplu öğretim ilkesine göre oluşturulan hayat bilgisi dersini, çocuğun kendisini, içinde yaşadığı toplumu ve dünyayı tanımayı sağlayan bir ders olarak kabul etmektedir. Süreç içinde yaşanan siyasi, ekonomik, sosyal ve teknolojik değişimlere uyum sağlama amacıyla hayat bilgisi öğretim programında değişiklikler yapılmıştır. Son değişikliğin yapıldığı 2018 hayat bilgisi öğretim programının amacı bu kapsamda "temel yaşam becerilerine sahip, kendini tanıyan, sağlıklı ve güvenli bir yaşam süren, yaşadığı toplumun değerlerini özümseyen, doğaya ve çevreye duyarlı, araştıran, üreten ve ülkesini seven bireyler yetiştirmek" olarak açıklanmıştır (MEB, 2018). Böylelikle öğrencilere temel yaşam becerilerinin kazandırılması amaçlanmıştır. Nitekim temel yaşam becerileri 2004-2005 hayat bilgisi öğretim programı ile başlamış ve 2009, 2015 ve son olarak 2018 yılında yapılan değişikliklerde programların amacı olarak ele alınmıştır.

Yaşam becerileri kavramı 1965 yılında Winthrop, Adkins ve Rosenberg tarafindan gençlere yönelik hazırlanan bir eğitim programında kullanılmıştır (Conger ve Mullen, 1981). Daha sonra 1980'lerde Dünya Sağlık Örgütü (DSÖ), sağlık alanında ilerleme için hazırladığı programda yaşam becerilerini; günlük yaşamdaki ihtiyaçlar ve karşılaşılan zorluklarla etkili bir şekilde başa çıkmayı sağlayan olumlu ve uyarlanabilir davranışlar içeren beceriler olarak tanımlamıştır (DSÖ, 1997). Tanımdaki "uyarlanabilir" olma durumu esneklik ve farklı durumlara uyum sağlama olarak açıklanırken "olumlu davranış" ise kişinin zor durumlarda veya gelecekte karşılaştığı sorunlara çözüm bulmak için umudunun olması ve firsat bulma çabasına karşılık gelmektedir (Dange, 2016). İnsanın gelişim alanlarına vurgu yapan Powell (1995) ise yaşam becerilerini psikolojik, fiziksel, cinsel, ahlaki, bilişsel, ego, duygusal ve mesleki süreçlerinin gelişimsel görevleri ile uyumlu olarak hayatta karşılaştığ 1 zorluklarla başa çıkmalarını sağlayan beceriler olarak açıklamaktadır. Zorluklarla etkili bir şekilde baş edebilmede yaşam becerileri eğitimi büyük öneme sahiptir. Bu bağlamda yaşam becerileri eğitimi ile bireylerin yaşamında karşılaştığ $1 /$ karşılaşacağ 1 risk faktörlerini en aza indirmek ve koruyucu faktörleri en üst seviyeye çıkarmak amaçlanmaktadır (UNICEF, 2015, s.5). Yaşam 
becerileri eğitimi ile bireyi sosyal ve sağlık problemlerine karşı korumak ele alınmaktadır. Bireyin psikolojik, biyolojik ve sosyal değişimlerle karşılaştığında bunlarla yüzleşmesi veya değişime ayak uydurması yaşam becerileri eğitimi ile sağlanabilir (Snow, 1985, s. 88). Bunun yanı sıra DSÖ'nün (1999) Cenevre'de yapılan toplantısında bireyin sağlıklı gelişimi, çocuk ve ergenlerin ölüm, hastalık ve sakatlığına neden olan durumlarını önlemek, sosyalleşme ile bireyi değişen koşullara hazırlamak için temel yaşam becerilerinin gerekli olduğuna vurgu yapmaktadır. Özmete $(2011$, s. 6) ise yaşam becerileri eğitimini bireylerin sağlıklı seçimler yapmasını, kendi kapasitelerini analiz etmelerini, diğer insanlarla anlaşabilmelerini, çevrelerine uyum sağlayabilmeleri, sorumlulukla karar verebilmelerini, kendilerine değer vermelerini ve zorlu koşullarda güçlenmelerini sağlamak olarak açıklamaktadır. Bu açıklamaya göre bireyin içinde yaşadığı topluma uyum sağlaması, sorunlarıyla başa çıkması ve kaliteli bir yaşam sürmesi için temel yaşam becerilerini edinmiş olmasının oldukça önemli olduğu söylenebilir.

Ekonomik İş birliği ve Kalkınma Örgütü (Organisation for Economic Co-operation and Development-OECD) Yetişkin Becerileri Araştırması 2016 raporunun sonuçlarına göre Türkiye'de yetişkinler sözel beceriler, sayısal beceriler ve teknoloji yoğun ortamlarda problem çözme becerileri olmak üzere üç beceri alanında da OECD ülkeleri ortalamasının oldukça altında bir performans sergilemiştir. Raporda ayrıca yetişkinlerin zorunlu eğitimden sonra beceri kazanmadığı, işyerinde ve günlük hayatta becerilerini kullanamadıkları da belirtilmektedir (OECD, 2016). Yetişkinlerin temel yaşam becerilerinde istenilen performansı neden sergileyemediklerini anlamak için önceki yıllarda aldıkları eğitimin niteliğini ve programların içeriğini sorgulamak gerekir. Temel eğitim pek çok yurttaş için zorunlu ve evrensel bir hak olduğu için eğitimin niteliğinin sorgulanmasına temel eğitim basamağından başlamak önemlidir. Bu basamak bireyin yaşamı boyunca kullanacağı bilgi ve becerilerin kazanılması açısından da temel olma özelliğine sahiptir. Temel yaşam becerilerinin kazandırılmasında en etkin derslerden biri hayat bilgisidir. Ancak 2004-2005 ve 2009 hayat bilgisi öğretim programlarında kazanımların temel yaşam becerilerine göre dağılımı yapılmış olmasına rağmen; 2015 ve 2018 programlarında kazanımların temel yaşam becerilere göre dağılımı yapılmamıştır. $\mathrm{Bu}$ dağılımın yapılması, programın uygulayıcısı olan sınıf öğretmenlerine hayat bilgisi öğretim programının kazanımlar ile ulaşılmak istenen yaşam becerileri arasındaki ilişkiyi ortaya koyması açısından yol gösterici olacağı umulmaktadır. Ayrıca kazanımların becerilere göre dağılımı ve sınıf öğretmenlerinin kazanımlara ulaşma düzeyine dönük görüşlerinin alınması programın etkililiğini değerlendirmek açısında da önemli veriler sunabilecektir. Bununla birlikte alanyazında hayat bilgisi dersine yönelik öğretmen görüşlerini ele alan araştırmalar (Altun ve Güler, 2020; Ekmen ve Demir, 2019; Erbil ve Doğan, 2019; Karabörk, 2020; Öztürk ve Kalafatçı, 2016; Sağlam, Babayiğit, Gökçe ve Yılmaz, 2019; Ünsal, 2018; Tuncer, 2009) bulunmaktadır. $\mathrm{Bu}$ araştırmanın da mevcut araştırmalara yeni bir boyut kazandırma ve güncel veriler sunma açısından önemli olduğu düşünülmektedir.

\section{YÖNTEM}

2018 hayat bilgisi öğretim programındaki temel yaşam becerilerinin kazanımlara göre dağılımını ve 2018-2019 öğretim yılında uygulanan hayat bilgisi öğretim programının kazanımlarının sınıf öğretmenlerinin görüşlerine göre amacına ulaşma düzeyini belirlemek amacıyla yapılan bu araştırmada tarama modeli kullanılmıştır. Tarama araştırma modeli, geçmiște ya da halen var olan bir durumu var olduğu șekliyle betimlemeyi amaçlayan araștırma yaklaşımı olup araştırma konusu kendi koşulları içinde ve var olan şekliyle müdahale edilmeden ortaya konur (Karasar, 2011, s. 77; Sönmez ve Alacapınar, 2013, s. 48). Tarama modeli bireylerin tutum, eylem, fikir veya inançlarını belirlemede tercih edilen bir yöntem olduğundan değişkenler arasındaki ilişkileri incelemeye, tahminler yapmaya ve alt grupların nasıl değiştiğini belirlemeye de yardımcı olmaktadır (Christen, Johnson ve Turner, 2015, s. 371). Bununla birlikte incelenen olgu veya durumu kontrol etme, müdahale etme veya akışını değiştirme söz 
konusu değildir (Sönmez ve Alacapınar, 2013, s. 48). Tanımlardan hareketle çalışmada 20182019 öğretim yılında uygulanan hayat bilgisi öğretim programındaki kazanımların amacına ulaşma düzeyini belirlemek için sınıf öğretmenlerinin görüşleri herhangi bir müdahale ve kontrol olmaksızın var olduğu haliyle incelenmiştir.

\section{1. Çalışma Grubu}

2018 hayat bilgisi öğretim programı temel yaşam becerilerinin kazanımlara göre dağılımını ve 2018-2019 öğretim yılında uygulanan hayat bilgisi öğretim program kazanımlarının sınıf öğretmenlerinin görüşlerine göre amacına ulaşma düzeyini belirlemek amacıyla yapılan bu araştırmada hem hız ve pratiklik sağladığ olduğundan (Yıldırım ve Şimşek, 2013, s. 141) kolay ulaşılabilir örnekleme yöntemi benimsenmiştir. Buna göre araştırmanın katılımcılarına ait kişisel bilgiler Tablo 1'de gösterilmiştir.

Tablo 1. Sınıf Öğretmenlerine Ait Kişisel Bilgiler

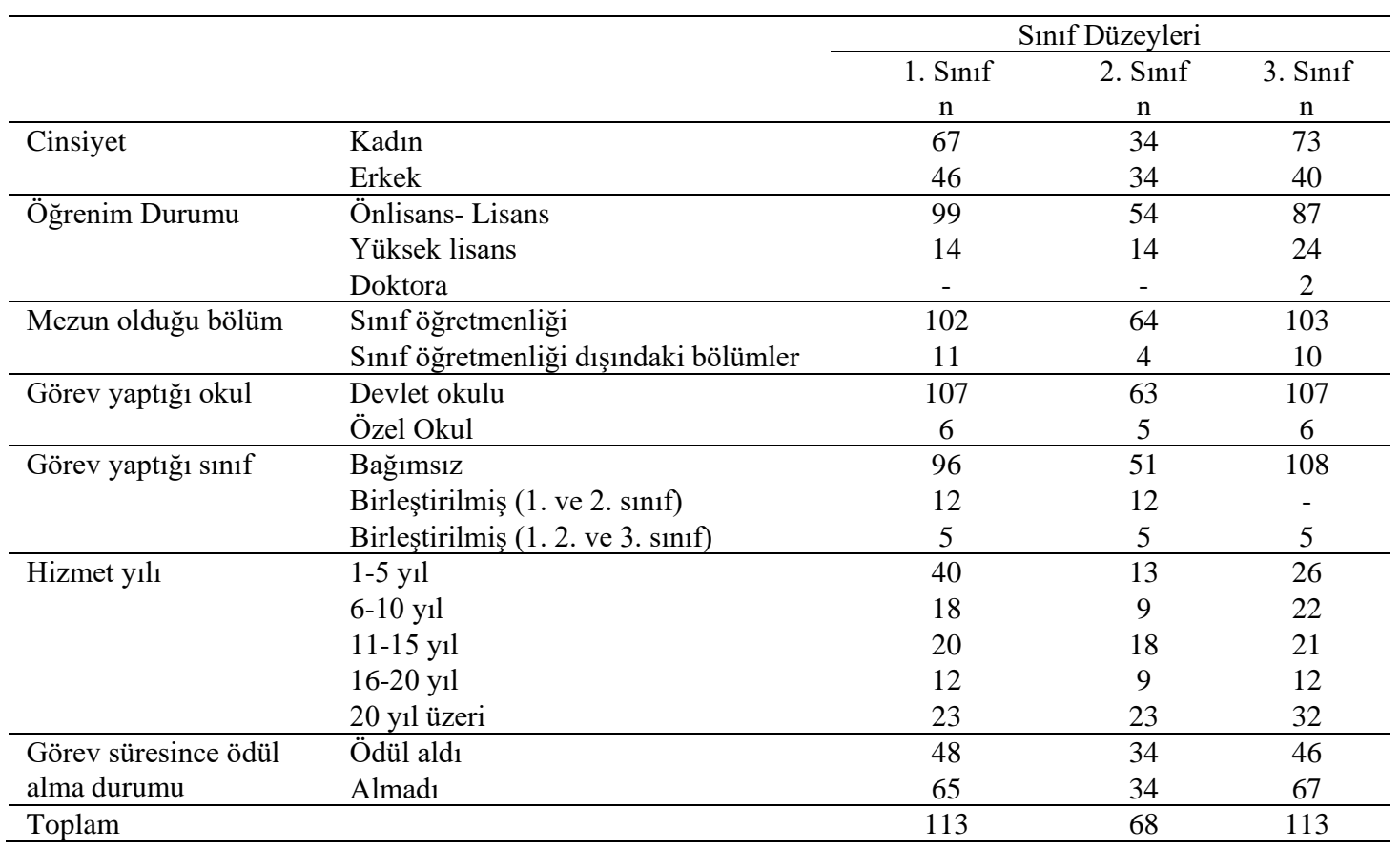

Tablo 1'de görüldüğü üzere araştırmaya katılan 294 sınıf öğretmenin 174'ü kadın, 120'si erkek olup birinci sınıf için hazırlanan ankete 113, ikinci sınıf için hazırlanan ankete 68 ve üçüncü sınıf için hazırlanan ankete 113 sınıf öğretmeni cevap vermiştir. Önlisans-lisans düzeyinde 240 yüksek lisans ve doktora mezunu olan 54 sınıf öğretmeni bulunmaktadır. Sınıf öğretmenlerinden 277'si devlet okulunda görev yaparken 17'si özel okulda görev yapmaktadır. Bununla birlikte bağımsız sinıflarda öğretim yapan 255 , 1. ve 2. sinıfların birleştirildiği sınıflarda öğretim yapan 24 ve ilk üç sınıfın birleştiği sınıflarda 15 sinıf öğretmeni görev yapmaktadır. Ayrıca öğretmenlerin hizmet yılı esas alındığında 79 sınıf öğretmeni 1-5 yıllık, 49 sınıf öğretmeni 6-10 yıllık, 59 sınıf öğretmeni 11-15 yıllık, 33 sinıf öğretmeni 16-20 yıllık, 20 ve üzeri hizmet yılına sahip 78 sınıf öğretmeni araştırmaya katılım sağlamıştır. Ayrıca öğretmenlerden 128'i görev süresinde maaş, teşekkür, takdir gibi farklı ödüller alırken 166 öğretmen ödül almamıştır.

\section{Veri Toplama Araçları}

Araştırmanın verilerini toplamak amacıyla "2018 Hayat Bilgisi Öğretim Programındaki Yaşam Becerilerinin Kazanımlara Göre Dağılım Formu" ve "Hayat Bilgisi Öğretim Programı Kazanımlarına Yönelik Öğretmen Görüşleri” anketleri kullanılmıştır. 
2.1. 2018 Hayat Bilgisi Öğretim Programındaki Yaşam Becerilerinin Kazanımlara Göre Dağılım Formu: 2018 hayat bilgisi öğretim programındaki temel yaşam becerilerinin kazanımlara göre dağılımı araştırmacı ve iki sınıf öğretmeni tarafından incelenmiştir. Sınıf öğretmenleri 148 kazanımda 126 kazanımın doğru dağılım gösterdiğini belirtmiş̧tir. Bununla birlikte sınıf öğretmenlerinin değerlendirmeleri arasında görüş birliği oluşturmak amacıyla Miles ve Huberman'ın (1994, s. 64) güvenirlik formülü kullanılmıştır. Sınıf öğretmenleri 147 kazanımda görüş birliği sağlarken görüş ayrılığının olduğu toplam kazanım sayısı 148'dir. Uygulanan formül sonucunda kazanımların dağılımında güvenirlik oranı \%99 olarak belirlenmiştir.

2.2. Hayat Bilgisi Öğretim Programı Kazanımlarına Yönelik Öğretmen Görüşleri: 2018-2019 ögretim y1lında ilkokullarda uygulanan hayat bilgisi öğretim programında yer alan kazanımların öğrencilere kazandırılabilme durumunu incelemek amacıyla birinci araştırmacı tarafından internet üzerinden ulaşılabilecek anketler oluşturulmuştur. 2018-2019 y1lında ikinci ve üçüncü sınıflarda 2015 hayat bilgisi öğretim programı uygulanmasından dolayı 2015 ve 2018 öğretim programının ikinci ve üçüncü sınıf kazanımları karşıllaştırılmıştır. Yapılan karşılaştırmada kazanımlar arasında büyük fark olmadığından ikinci ve üçüncü sınıf kazanımları 2015 programına göre oluşturulmuştur. Bu kapsamda birinci sınıf için hazırlanan anket 53 kazanım, ikinci sınıf için hazırlanan anket 50 kazanım, üçüncü sınıf için hazırlanan ankette ise 42 kazanım yer almaktadır. Hazırlanan anketler 7'li likert ölçeğine uygun olarak düzenlenmiş olup " $1=$ Kesinlikle Katılmıyorum" ile " $7=$ Kesinlikle Katılıyorum" olarak düzenlenmiştir. Anketler bir eğitimde ölçme değerlendirme uzmanı, bir hayat bilgisi öğretim uzmanı ve bir sınıf öğretmenine gönderilmiş ve gelen dönütler esas alınarak anketler düzenlenmiştir. Okullarda kazanımların tamamının öğretilmesi yani programın bitiş tarihi öğretim yılının sonu olduğundan anket 17 Haziran 2019- 23 Ağustos 2019 tarihleri arasında elektronik posta ve sosyal medya yoluyla öğretmenlerle paylaşılmıştır. Uygulanan anketlerin güvenirliliği ölçmek için veri toplama araçlarının iç tutarlılı̆̆ maddelerin belirli kavramsal yapıyı tutarlı bir şekilde ölçüp ölçmediğinin belirlenmesidir (Şencan, 2005, s. 107). Uygulanan anketlerin iç tutarlılık katsayı hesaplanmak için Cronbach Alfa $(\alpha)$ değerleri incelenmiş uygulanan anketlerin tamamında Cronbach Alfa $(\alpha)$.98 olarak belirlenmiştir.

\section{Verilerin Analizi}

2018 hayat bilgisi öğretim programı için belirlenen birinci, ikinci ve üçüncü sınıf kazanımlarının (148) dağılımı programda belirtilen 23 temel yaşam becerisine göre incelenmesinde betimsel analiz yöntemi kullanılmıştır. Betimsel analiz, verilerin daha önce belirlenen temalara göre özetlenip yorumlanmasına dayanmaktadır. Betimsel analizde veriler, araştırma sorularına dayalı olarak ortaya konulan temalara göre düzenlenebileceği gibi veri toplama aracında kullanılan sorular ya da boyutlar dikkate alınarak da oluşturulabilir (Yıldırım ve Şimşek, 2013, s. 256). Bu araştırma kapsamında da programda yer alan 23 temel yaşam becerisinin alanyazındaki açıklamaları ve 2009 hayat bilgisi öğretim programında becerilerin göstergeleri dikkate alınmıştır. Hayat bilgisi öğretim programında yer alan 126 kazanımın program çerçevesinde belirtilen temel yaşam becerileri ile uyumlu olduğu sonucuna ulaşıllmıştır. Becerilerin kazanımlarına göre dağılımı incelenirken alanyazında yer alan açıklamalar ve 2009 hayat bilgisi öğretim programında yer alan beceri aşamalara göre ele alınmıştır. Örneğin; "1.3.2. Sağlığını korumak için alması gereken önlemleri fark eder." kazanımı "Temiz ve güvenli bir çalışma çevresi oluşturma, Sağlığı ve güvenliği için kişisel sorumluluğunu açıklama" (MEB, 2009) açıklamalardan hareketle "Sağlığını Koruma" becerisi altında ele alınmıştır. Bununla birlikte verilerin tablo gösteriminde MEB (2015) açıklamalarına göre "Sınıf Düzeyi, Ünite Numarası, Kazanım numarası" şeklinde kodlanmıştır. Örnekle açıklamak gerekirse "1.2.3." kodlamasında " $1=$ sınıf düzeyi", " $2=$ ünite numarası", " $3=$ kazanım numarası" olarak ele alınmıştır. Açıklanan kazanım bu durumda birinci sınıf hayat bilgisi öğretim programının ikinci ünitesinde yer alan üçüncü kazanımı göstermektedir. 
Programın kazanımlarının amacına ulaşma düzeyine yönelik öğretmen görüşlerine dayalı veriler ise betimsel istatistik yolu ile analiz edilmiştir. Betimsel istatistik, belirli bir veri kümesini tanımlamak, özetlemek ya da anlamlandırmaktır (Johnson ve Christen, 2014, s. 451). $\mathrm{Bu}$ bağlamda anketlerde yer alan kazanımların aritmetik ortalama, standart sapma ve yüzde hesaplamaları ele alınmıştır. Ankette yer alan maddelerden en yüksek aritmetik ortalama 6,58 olup en düşük aritmetik ortalama değeri 4,30 olduğundan 6,58- 5,82 arasındaki değerler için "Yüksek", 5,81-5,05 arasındaki değerler "Orta", 5,04 ve altında yer alan değerler "Düşük" kazandırılabilme durumuna sahip olarak değerlendirilmiştir

\section{Araştırmanın etik izinleri}

Yapılan bu çalışmada "Yükseköğretim Kurumları Bilimsel Araştırma ve Yayın Etiği Yönergesi" kapsamında uyulması belirtilen tüm kurallara uyulmuştur. Yönergenin ikinci bölümü olan "Bilimsel Araştırma ve Yayın Etiğine Aykırı Eylemler" başlığı altında belirtilen eylemlerden hiçbiri gerçekleştirilmemiştir.

Etik değerlendirmeyi yapan kurul adı = Hakkâri Üniversitesi

Etik değerlendirme kararının tarihi=18/06/2020

Etik değerlendirme belgesi sayı numarası=BE6L2V3L

\section{BULGULAR}

Temel yaşam becerileri kazandırmayı amaçlayan hayat bilgisi öğretim programın kazanımları ve temel yaşam becerilerinin dağılımı Tablo 2'de yer almaktadır.

Tablo 2. 2018 Hayat Bilgisi Öğretim Programının Becerileri ve Kazanımlarının Dağılımı

\begin{tabular}{|c|c|c|c|c|}
\hline \multirow{2}{*}{2018 Temel Yaşam Becerileri } & \multicolumn{3}{|c|}{ Kazanımlar } & \multirow{2}{*}{ Toplam } \\
\hline & 1. sinif & 2. sinif & 3. sinif & \\
\hline Araştırma & 1.6.7. & $\begin{array}{l}2.2 .6 \\
2.5 .3 \\
2.6 .9 \\
2.5 .6\end{array}$ & $\begin{array}{l}3.5 .6 . \\
3.5 .8 \\
3.5 .9 \\
3.6 .2\end{array}$ & 9 \\
\hline Bilgi ve İletişim Teknolojilerini Kullanma & 1.4 .6 & 2.4 .5 . & 3.2.5. & 3 \\
\hline Değişim ve Sürekliliği Algılama & & & 3.2.1. & 1 \\
\hline Dengeli Beslenme & 1.3.4. & 2.3.2. & 3.3.4. & 3 \\
\hline Doğayı Koruma & $\begin{array}{l}1.6 .3 . \\
1.6 .4 . \\
1.6 .5 . \\
1.6 .8 .\end{array}$ & $\begin{array}{l}2.6 .1 . \\
2.6 .2 . \\
2.6 .3 . \\
2.6 .4 \\
2.6 .5 \\
2.6 .6 \\
2.6 .7\end{array}$ & $\begin{array}{l}3.6 .1 . \\
3.6 .4 \\
3.6 .5 . \\
3.6 .6 .\end{array}$ & 15 \\
\hline Girişimcilik & & & $\begin{array}{l}3.2 .6 . \\
3.1 .9 .\end{array}$ & 2 \\
\hline Gözlem & $\begin{array}{l}1.4 .2 . \\
1.6 .1 . \\
1.6 .2 . \\
1.6 .6 .\end{array}$ & $\begin{array}{l}2.5 .8 . \\
2.6 .8 .\end{array}$ & & 6 \\
\hline İletişim & $\begin{array}{c}1.1 .1 . \\
1.1 .13 . \\
1.2 .4\end{array}$ & $\begin{array}{l}2.1 .8 . \\
2.1 .9 .\end{array}$ & 3.1.8. & 6 \\
\hline İşbirliği & & 2.1.7. & & 1 \\
\hline Karar Verme & 1.1.17. & $\begin{array}{l}2.1 .4 . \\
2.2 .5 \text {. }\end{array}$ & & 3 \\
\hline Kariyer Bilinci Geliştirme & & 2.3 .5 . & 3.1.10. & 2 \\
\hline Kaynakların Kullanımı & 1.2.5. & $\begin{array}{c}2.1 .6 \\
2.1 .11\end{array}$ & $\begin{array}{l}3.2 .8 . \\
3.3 .1 . \\
3.5 .5\end{array}$ & 6 \\
\hline Zaman Yönetimi & 1.2.6. & 2.2 .8 . & 3.2.7. & 3 \\
\hline
\end{tabular}




\begin{tabular}{|c|c|c|c|c|}
\hline Sosyal Katılım & 1.1.11. & $\begin{array}{l}2.2 .7 \\
2.4 .3\end{array}$ & $\begin{array}{l}3.1 .7 . \\
3.5 .7 .\end{array}$ & 5 \\
\hline Sorun Çözme & & & 3.5.7. & 1 \\
\hline Sağlığını Koruma & $\begin{array}{l}1.3 .2 . \\
1.3 .3 . \\
1.3 .5 . \\
1.3 .7 .\end{array}$ & $\begin{array}{l}2.3 .1 . \\
2.3 .4 \\
2.3 .6 \\
2.3 .7\end{array}$ & $\begin{array}{l}3.3 .3 . \\
3.3 .4 . \\
3.3 .5\end{array}$ & 11 \\
\hline Öz Yönetim & 1.1.15. & & $\begin{array}{l}3.1 .2 . \\
3.1 .3 . \\
3.1 .4 .\end{array}$ & 4 \\
\hline Millî ve Kültürel Değerleri Tanıma & $\begin{array}{l}1.1 .6 . \\
1.2 .2 . \\
1.5 .3 . \\
1.5 .5 . \\
1.5 .6 . \\
1.5 .7 .\end{array}$ & $\begin{array}{l}2.2 .2 . \\
2.5 .2 . \\
2.5 .4 . \\
2.5 .5 . \\
2.5 .6\end{array}$ & $\begin{array}{l}3.2 .2 \text {. } \\
3.5 .6 \text {. }\end{array}$ & 13 \\
\hline Mekânı Algılama & $\begin{array}{l}1.1 .4 . \\
1.1 .5 . \\
1.1 .7 . \\
1.2 .3 . \\
1.5 .1 . \\
1.5 .2 .\end{array}$ & $\begin{array}{l}2.1 .5 \\
2.2 .3 \\
2.5 .1\end{array}$ & $\begin{array}{l}3.1 .5 . \\
3.2 .3 . \\
3.5 .3\end{array}$ & 12 \\
\hline Kurallara Uyma & $\begin{array}{c}1.1 .3 . \\
1.1 .12 . \\
1.1 .13 . \\
1.3 .6 . \\
1.4 .1 . \\
1.4 .3 .\end{array}$ & $\begin{array}{c}2.1 .7 \\
2.1 .10 \\
2.3 .3 \\
2.4 .2\end{array}$ & $\begin{array}{l}3.3 .5 \text {. } \\
3.4 .2 \text {. }\end{array}$ & 12 \\
\hline Kendini Tanıma & 1.1.2. & 2.1 .1$. & 3.1.1. & 3 \\
\hline Kişisel Bakım & $\begin{array}{l}1.1 .8 . \\
1.3 .1 .\end{array}$ & & & 2 \\
\hline Kendini Koruma & $\begin{array}{l}1.4 .4 . \\
1.4 .5 \\
1.4 .7\end{array}$ & $\begin{array}{l}2.4 .4 \\
2.4 .6\end{array}$ & $\begin{array}{l}3.4 .3 . \\
3.4 .4 . \\
3.4 .5 . \\
3.4 .6 . \\
3.4 .7 .\end{array}$ & 10 \\
\hline Toplam & 47 & 45 & 41 & 133 \\
\hline
\end{tabular}

2018 hayat bilgisi öğretim programının kazanım ve becerilerinin karşılaştırıldığı Tablo 2'ye göre bir, iki ve üçüncü sınıflar için hazırlanan 2018 hayat bilgisi öğretim programında toplam 148 kazanım bulunmaktadır. Bu kazanımların 126'sı programda yer alan temel yaşam becerileri ile uyumludur. Ayrıca birinci sınıf için hazırlanmış olan "1.1.13. Okulda iletişim kurarken nezaket kurallarına uyar" iletişim ve kurallara uyma becerisi ile ikinci sınıf için hazırlanan "2.1.7. Sınıfta ve okulda yapılan etkinliklerde grupla çalışma kurallarına uyar" kazanımı kurallara uyma ve iş birliği becerileri ile "2.5.6. Yakın çevresindeki kültürel miras ögelerini araştırır" kazanımı da araştırma ve milli ve kültürel değerleri tanıma becerisi ilişkilendirilebilir. Bununla birlikte üçüncü sınıf için hazırlanan "3.3.4 Sağlığını korumak için yeterli ve dengeli beslenir" kazanımı sağlığını koruma ve dengeli beslenme becerileri ile "3.3.5. Kendisinin ve toplumun sağlı̆̆ını korumak için ortak kullanım alanlarında temizlik ve hijyen kurallarına uyar" kazanımı sağlığını koruma ve kurallara uyma becerileri ile, "3.5.6. Millî birlik ve beraberliğin toplum hayatına katkılarını araştırır" kazanımı araştırma ile millî ve kültürel değerleri tanıma becerileri ile "3.5.7. Ülkemizde yaşayan farklı kültürdeki insanların sorunlarına yönelik sosyal sorumluluk projelerine katılır" kazanımı sorun çözme ve sosyal katılım becerileriyle açıklanmaktadır.

Tablo 2'de görüldüğü üzere kazanımların temel yaşam becerilerine eşit dağılmadığı söylenebilir. Ayrıca "Doğay1 Koruma" becerisi için 15, "Mekânı Algılama" becerisi için 12, "Sağlığını Koruma" becerisi için ise toplam 11 kazanım yer almaktadır. Buna karşın "İş birliği", "Değişim ve Sürekliliği Algılama" ve "Sorun Çözme" becerilerine yeterince yer verilmediği söylenebilir. 
2018-2019 öğretim yılında birinci sınıf hayat bilgisi öğretim programının kazanımlarının sınıf ögretmenlerinin görüşlerine göre kazandırılma durumları Tablo 3 'te gösterilmiştir.

Tablo 3. Birinci Sınıf Hayat Bilgisi Öğretim Programı Kazanımlarının Gerçekleşme Durumuna İlişkin Sınıf Öğretmenlerinin Görüşlerinin Betimsel İstatistik Sonuçları

\begin{tabular}{|c|c|c|c|c|c|}
\hline \multirow{2}{*}{ Kazanımlar } & \multirow{2}{*}{$\overline{\mathrm{x}}$} & \multirow{2}{*}{ SS } & \multicolumn{3}{|c|}{$\%$} \\
\hline & & & $1-2-3$ & 4 & $5-6-7$ \\
\hline Sınıf içi tanışma etkinliğine katılır & 6,03 & 1,31 & 5,3 & 9,7 & 85,0 \\
\hline Kendisiyle akranları arasındaki benzer ve farklı yönleri ayırt eder & 5,65 & 1,29 & 8,0 & 9,7 & 82,3 \\
\hline Sınıfının okul içindeki yerini bulur & 6,58 & 0,92 & 1,8 & 2,7 & 95,5 \\
\hline Sınıf içerisinde bulunan ders araç ve gereçleri ile şeref köşesini tanır & 6,32 & 1,01 & 1,8 & 3,5 & 94,7 \\
\hline Bayrak töreninde nasıl davranması gerektiğini kavrar & 5,99 & 1,27 & 5,3 & 5,3 & 89,4 \\
\hline Tuvalet kullanma ve temizlik alışkanlığı geliştirir & 5,50 & 1,42 & 8,0 & 11,5 & 80,5 \\
\hline Okul çalışanlarını tanır & 6,04 & 1,25 & 5,3 & 2,7 & 92,0 \\
\hline İhtiyaç duyduğu durumlarda okul çalışanlarından yardım alır & 5,91 & 1,29 & 4,4 & 7,1 & 88,5 \\
\hline Sınıf içi kuralları belirleme sürecine katılır & 5,70 & 1,38 & 9,7 & 5,3 & 85,0 \\
\hline Okul kurallarına uyar & 5,45 & 1,25 & 5,3 & 15,0 & 79,7 \\
\hline Okulda iletişim kurarken nezaket kurallarına uyar & 5,39 & 1,39 & 8,8 & 12,4 & 78,8 \\
\hline Kullanacağı ders araç ve gereçlerini seçer & 5,69 & 1,37 & 8,0 & 10,6 & 81,4 \\
\hline Aile bireylerini tanıtır & 6,26 & 1,13 & 2,7 & 7,1 & 90,2 \\
\hline Aile hayatının önemini kavrar & 5,96 & 1,15 & 3,5 & 6,2 & 90,3 \\
\hline Evinin yerini tarif eder & 5,37 & 1,45 & 11,5 & 11,5 & 77,0 \\
\hline Evde aile bireyleri ile iletişim kurarken nezaket kurallarına uyar & 5,27 & 1,49 & 12,4 & 11,5 & 76,1 \\
\hline Evdeki kaynakları verimli bir şekilde kullanır & 5,26 & 1,46 & 11,5 & 13,3 & 75,2 \\
\hline Gün içerisinde neler yapabileceğini planlar & 4,67 & 1,66 & 21,2 & 22,1 & 56,7 \\
\hline İstek ve ihtiyaçları arasındaki farkı ayırt eder & 5,26 & 1,50 & 15,9 & 8,8 & 75,3 \\
\hline Kişisel bakımını düzenli olarak yapar & 5,23 & 1,55 & 13,3 & 15,0 & 71,7 \\
\hline Sağlığını korumak için alması gereken önlemleri fark eder & 5,29 & 1,49 & 9,7 & 15,9 & 74,4 \\
\hline Sağlı̆̆ı için yararlı yiyecek ve içecekleri seçer & 4,96 & 1,74 & 18,6 & 18,6 & 62,8 \\
\hline Çevresindeki kişilerle iletişim kurarken güvenlik kurallarını uygular & 5,23 & 1,64 & 15,9 & 12,4 & 71,7 \\
\hline Acil durumlarda yardım almak için arayacağı kurumların telefon numaralarını bilir & 5,76 & 1,55 & 11,5 & 4,4 & 84,1 \\
\hline Teknolojik araç ve gereçleri güvenli bir şekilde kullanır & 5,02 & 1,65 & 17,7 & 15,9 & 66,4 \\
\hline Kendisi için güvenli ve güvensiz alanları ayırt eder & 5,49 & 1,61 & 10,4 & 12,6 & 77,0 \\
\hline Yaşadığı yeri bilir & 5,83 & 1,48 & 8,8 & 7,1 & 84,1 \\
\hline Yakın çevresindeki tarihî, doğal ve turistik yerleri fark eder & 4,71 & 1,81 & 27,4 & 8,8 & 63,8 \\
\hline Ülkemizin genel özelliklerini tanır & 4,62 & 1,76 & 24,8 & 20,4 & 54,8 \\
\hline Ülkemizde, farklı kültürlerden insanlarla bir arada yaşadığını fark eder & 5,12 & 1,77 & 22,1 & 5,3 & 72,6 \\
\hline Atatürk'ün hayatını bilir & 6,05 & 1,20 & 3,5 & 5,3 & 91,2 \\
\hline Millî gün, bayram, tören ve kutlamalara katılmaya istekli olur & 6,25 & 1,14 & 2,7 & 6,2 & 91,1 \\
\hline Dinî gün ve bayram kutlamalarına istekle katılır & 6,27 & 1,17 & 4,4 & 3,5 & 92,1 \\
\hline Yakın çevresinde bulunan hayvanları gözlemler & 6,15 & 1,26 & 5,3 & 7,1 & 87,6 \\
\hline Yakın çevresinde bulunan bitkileri gözlemler & 6,05 & 1,23 & 4,4 & 7,1 & 88,5 \\
\hline Yakın çevresinde bulunan hayvanları ve bitkileri korumaya özen gösterir & 5,96 & 1,23 & 5,3 & 6,2 & 88,5 \\
\hline Doğayı ve çevresini temiz tutma konusunda duyarlı olur & 5,85 & 1,32 & 5,3 & 8,8 & 85,9 \\
\hline Geri dönüşümü yapılabilecek maddeleri ayırt eder & 5,70 & 1,57 & 11,5 & 6,2 & 82,3 \\
\hline Güneş, Ay, Dünya ve yıldızları gözlemler & 5,49 & 1,65 & 12,4 & 6,2 & 81,4 \\
\hline Mevsimleri ve özelliklerini araştırır & 5,69 & 1,34 & 8,8 & 6,2 & 85,0 \\
\hline Mevsimlere göre doğada meydana gelen değişiklikleri kavrar & 5,85 & 1,28 & 7,1 & 5,3 & 87,6 \\
\hline
\end{tabular}

Tablo 3’te görüldüğü gibi birinci sınıf hayat bilgisi öğretim programında yer alan 53 kazanımdan 21 kazanımın aritmetik ortalama değerleri 6,58 ile 5,82 arasında ve oldukça "yüksek" tir. Ayrıca 25 kazanımın aritmetik ortalama değeri 5,81 ile 5,05 arasında olup standart sapma değerleri 1,25 ile 1,77 arasındadır. Öğretmenlerin görüşleri çerçevesinde 25 kazanımın 
orta düzeyde" olduğu görülmüştür. Aritmetik ortalama değeri 5,04 altında yer alan 7 kazanımın kazandırılma düzeyi "çok düşük" düzeydedir. Öğretmenler birinci sınıf için hazırlanan 53 hayat bilgisi öğretim programı kazanımından \%40'ının "yüksek" (21 kazanım); \%47'sinin "orta" (25 kazanım), \%13'ünün (7 kazanım) ise "düşük" düzeyde kazandırıldığını düşünmektedir.

Hayat bilgisi öğretim programı ikinci sınıf kazanımlarının gerçekleşme düzeyine yönelik öğretmen görüşleri Tablo 4'te gösterilmiştir.

Tablo 4. İkinci Sınıf Hayat Bilgisi Öğretim Programı Kazanımlarının Gerçekleşme Durumuna İlişkin Sınıf Öğretmenlerinin Görüşlerinin Betimsel İstatistik Sonuçları ( $\mathrm{n}=68)$

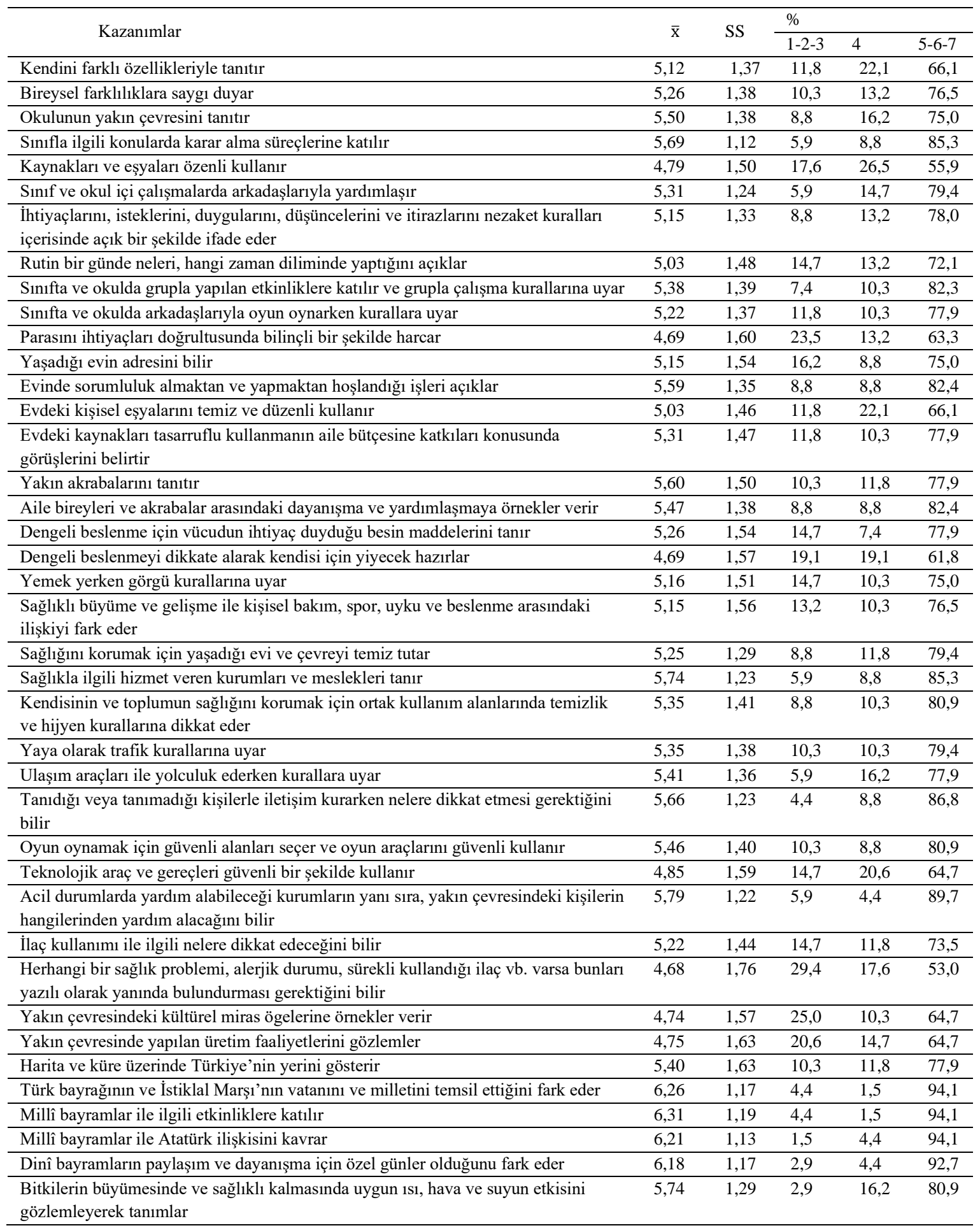




\begin{tabular}{|c|c|c|c|c|c|}
\hline $\begin{array}{l}\text { Bitkilerin büyümesinde ve sağlıklı kalmasında uygun 1sı, hava ve suyun etkisini } \\
\text { gözlemleyerek tanımlar }\end{array}$ & 5,76 & 1,27 & 4,4 & 10,3 & 85,3 \\
\hline Bitki yetiştirme ve ağaç dikmenin doğaya olan katkılarını kavrar & 6,19 & 1,12 & 1,5 & 7,4 & 91,1 \\
\hline $\begin{array}{l}\text { Hayvanların hayatlarını sürdürebilmesi için su, hava ve besinlere ihtiyacı olduğunu } \\
\text { açılar }\end{array}$ & 6,18 & 1,12 & 1,5 & 5,9 & 92,6 \\
\hline Çevresinde bulunan bitki ve hayvanları korur & 5,91 & 1,34 & 4,4 & 8,8 & 86,8 \\
\hline Güneşin hareketlerini gözlemleyerek yönleri gösterir & 5,24 & 1,55 & 13,2 & 13,2 & 73,6 \\
\hline Mevsimleri ve mevsimlere göre doğadaki değişiklikleri kavrar & 5,79 & 1,43 & 7,4 & 8,8 & 83,8 \\
\hline Doğa olayları sonucu oluşan doğal afetlere örnekler verir & 5,82 & 1,29 & 5,9 & 7,4 & 86,7 \\
\hline İnsanların çevre üzerinde olumsuz etkilerine örnekler verir & 5,65 & 1,29 & 5,9 & 10,3 & 83,8 \\
\hline İnsanların hangi davranışlarının çevre kirliliğine neden olduğunu gözlemler & 5,71 & 1,36 & 8,8 & 7,4 & 83,8 \\
\hline Tüketilen maddelerin geri dönüşümüne katkıda bulunur & 5,84 & 1,35 & 5,9 & 8,8 & 85,3 \\
\hline
\end{tabular}

Tablo 4'te görüldüğü gibi öğretmenler, ikinci sınıf için hazırlanan 50 hayat bilgisi öğretim programı kazanımından \%18'sinin (9 kazanım) "yüksek" düzeyde; \%64'ünün (32 kazanım) "orta” düzeyde \%18'inin (9 kazanım) ise düşük düzeyde kazandırıldığı görüşündedir.

Hayat bilgisi öğretim programı üçüncü sınıf kazanımlarının gerçekleşme düzeyine yönelik öğretmen görüşleri Tablo 5'te gösterilmiştir.

Tablo 5. Üçüncü Sınıf Hayat Bilgisi Öğretim Programı Kazanımlarının Gerçekleşme Durumuna İlişkin Sınıf Öğretmenlerinin Görüşlerinin Betimsel İstatistik Sonuçları ( $\mathrm{n}=113)$






\begin{tabular}{|c|c|c|c|c|c|}
\hline $\begin{array}{l}\text { Ülkesinin gelişmesi ile kendi görev ve sorumluluklarını yerine getirmesi } \\
\text { arasında bağlantı kurar }\end{array}$ & 4,92 & 1,71 & 19,5 & 12,4 & 68,1 \\
\hline Milletin ortak mallarını özenli kullanır ve korur & 5,13 & 1,70 & 15,0 & 14,2 & 70,8 \\
\hline Millî bayramlar ile ilgili etkinliklere katılır & 6,18 & 1,28 & 6,2 & 2,7 & 91,1 \\
\hline Dinî bayramların paylaşım ve dayanışma için özel günler olduğunu fark eder & 6,13 & 1,08 & 4,4 & 3,5 & 92,1 \\
\hline Doğadan yararlanarak yönleri bulur & 5,39 & 1,45 & 12,4 & 11,5 & 76,1 \\
\hline Meyve ve sebzelerin nasıl ve nerede yetiştirildiğinin farkına varır & 5,58 & 1,43 & 9,7 & 8,0 & 82,3 \\
\hline Yaşadığı yerde insanların doğal çevrede yaptıkları değişikliklere örnekler verir & 5,69 & 1,46 & 8,8 & 9,7 & 81,5 \\
\hline Çevresinde bulunan bitki ve hayvanları korur & 5,82 & 1,50 & 10,6 & 5,3 & 84,1 \\
\hline Doğa ve çevreyi koruma konusunda sorumluluk alır & 5,77 & 1,49 & 10,6 & 3,5 & 85,9 \\
\hline Geri dönüşüme bireysel olarak nasıl katkı sağlayacağını bilir & 5,91 & 1,31 & 8,0 & 2,7 & 89,3 \\
\hline
\end{tabular}

Tablo 5'e göre üçüncü sinıf için belirlenen 43 hayat bilgisi öğretim programı kazanımından \%21'i (9 kazanım) “yüksek", \%63'ü (27 kazanım) “orta”, \%16's1 (7 kazanım) ise "düşük" düzeyde kazandırılabilmektedir.

\section{TARTIŞMA, SONUÇ VE ÖNERILER}

2018 hayat bilgisi öğretim programının kazanımlarının becerilere göre dağılımı incelendiğinde 2018 hayat bilgisi öğretim programının kazanım ve temel yaşam becerileri karşılaştırıldığında 148 kazanımdan 126 kazanımın program çerçevesinde belirtilen 23 temel yaşam becerisi ile uyumlu olduğu sonucuna ulaş1lmıştır. Bir, iki ve üçüncü sınıfta yer alan toplam 22 kazanımın ise program çerçevesinde belirtilen temel yaşam becerileri ile açıklanmadığı söylenebilir. Bununla birlikte 126 kazanım program çerçevesinde belirtilen 23 temel yaşam becerisine eşit oranda dağılmamaktadır. Öztürk (2019) birinci sınıf hayat bilgisi konuları ile temel yaşam becerilerini karşılaştırdığı araştırmasında kitabın eksik olduğunu, "araştırma yapmaya" yönelik konu içeriklerinin sınırlı olmasına rağmen "kurallara uymaya" yönelik birçok konunun yer alması bulgusu kazanımların eşit dağılmadığı bulgusunu desteklemektedir. Ayrıca bazı temel yaşam becerilerine her sınıf seviyesinde yer verilmemiştir. Diğer bir ifade ile "Girişimcilik" becerisi sadece üçüncü sınıf kazanımlarında yer alırken "Karar verme" becerisine bir ve ikinci sınıfta toplam üç kazanımla yer verilmiştir. "Kariyer bilinci geliştirme" becerisi için iki ve üçüncü sınıfta iki kazanım yer almaktadır. "Özyönetim" becerisi ise bir ve üçüncü sınıf kazanımları ile ele alınmış olup ikinci sınıf kazanımlarında bu beceriye dönük kazanım bulunmamaktadır. Ayrıca "Kişisel bakım" becerisine yalnızca birinci sınıfta yer verilmiştir. 2005 ve 2009 hayat bilgisi öğretim programlarının sarmal öğretim ile hazırlandığ 2015 ve 2018 programlarında da bu durumun devam ettiği düşünüldüğünde hazırlanan bu ilkeye dikkat etmediği görülmektedir. Bununla birlikte ilkokul öğrencilerinin Erik Erikson'un psikososyal gelişim kuramına göre "girişkenliğe karşı suçluluk" evresi ile "başarıya karşı aşağılık duygusu" evrelerindedir. Bu evrelerde çocukların sosyalleşmesinin hem girişim ve başarı duygusunu güçlendireceği (Bee ve Boyd, 2009, s. 524) hem de benlik gelişimini olumlu yönde geliştireceği (Kılıçç1, 1992, s. 50) düşünülmektedir. Sullivan'ın kişilik kuramında ilkokul çocuğunun arkadaş gereksiniminin arttığ1 (Gümüş, 2017, s. 44) düşünüldüğünde iş birliği ve girişimcilik becerisi önem kazandığından bir kazanımın yetersiz olduğu söylenebilir. Ayrıca bireyin içinde yaşadığı toplumu, kültürü ve kendisini tanıması için geçmiş ve gelecek arasındaki ilişkiyi anlamalarını sağlayan değişim ve sürekliliği algılama becerisinin (Özen ve Sağlam, 2010) kazandırılması için bir kazanımın yeterli olmadığı düşünülmektedir. Bununla birlikte üst düzey bilişsel beceriler arasında yer alan ve her aşamasında farklı yetenek ve beceriler gerektirmesinin yanı sıra sosyalleşmeyi de gerektiren (Aydın, 2009) "sorun çözme becerisi" için yalnızca üçüncü sınıfta bir kazanıma yer verilmesinin öğrencinin sosyal ve bilişsel gelişimi açısından yetersiz olduğu söylenebilir.

Problem çözme, ilişkilendirme, sınıflama çıkarım yapma ve değerlendirme becerilerinin de gelişimini destekleyen "Karar Verme" (Doğanay, 2006, s. 186) becerisine ve temelinde 
araştırma- incelemenin yer aldığı "Gözlem" becerisine ise bir ve ikinci sınıfta yer verilmiştir. Bunun yanı sıra Ginzberg ve arkadaşlarına göre ilkokul çocuğunun meslek seçiminde fantezi dönemde, Super'e göre ise büyüme döneminde olduğu (aktaran Karagözoğlu ve Kemertaş, 2004, s. 106-108) dikkate alındığında "Kariyer bilinci geliştirme" becerisine iki ve üçüncü sınıfta iki kazanımla yer verilmesi yeterli görülmektedir. Bireyin kendini tanıması, farkında olması ve yönetmesi olarak tanımlanan "Özyönetim" becerisine (Karabağ ve İnal, 2009, s. 398) ikinci sınıf kazanımları arasında yer verilmemesi bir eksikliktir. Ayrıca 31 Aralık 2019'da başlayan COVID-19 salgınında hastalıktan korunma yollarından biri olarak görülen "Kişisel Bakım" (Türkiye Sağlık Bakanlığı, 2020) becerisine yalnızca birinci sınıf kazanımlarında yer verilmiştir ki öğrencinin sonraki süreçlerde kazanımı pekiştirmesi açısından bu durumun yetersiz olduğu söylenebilir. Çocuğun psikolojik özelliklerinin hayat bilgisi dersinin önem ve değerini arttırdığını belirten Binbaşıoğlu (2003, s. 66) hayat bilgisi dersinin çocukların nesnel düşünmesini sağlayıcı ve becerilerini geliştirici olması gerektiğini vurgulamaktadır. Ancak 2018 hayat bilgisi öğretim programının bu bağlamda yeterli olmadığı, öğrencilerin sosyal, kişilik, dil ve bilişsel gelişimi için önemli olan araştırma, sorun çözme, karar verme, girişimcilik, kişisel bakım becerilerine yeterince yer verilmediği görülmektedir. Karaman'ın (2019) bazı hayat bilgisi kazanımlarının öğrenci seviyesine uygun olmadığı bulgusu ve Öztürk'ün (2015) ögretmen görüşlerine göre hayat bilgisindeki temel yaşam becerilerini kazandırma bakımından yeterli; ancak eksikleri olduğu belirtildiği sonucuna ulaşması araştırma bulgularına kısmen paraleldir.

Temel yaşam becerilerini kazandırabilmek amacıyla hazırlanan 2018 hayat bilgisi öğretim programının 148 kazanımından 126'sının program çerçevesinde belirtilen yaşam becerileri ile uyumlu bulunduğu söylenebilir. Nitekim Ekmen ve Demir'in (2019) öğretmen görüşlerini inceledikleri araştırmalarında kazanımların sayısı yeterli olsa da günlük yaşama aktarmanın zor olduğu ve işlevsel olması gerekliliğine vurgu yapılmıştır. Ayrıca Altun ve Güler'in (2020) araştırmasında da programdaki kazanımların bazılarının soyut olduğu ve bu kazanımların gerçek yaşama aktarımının zor olduğu belirtilmektedir.

Hayat bilgisi öğretim programının kazanımlarını yüksek düzeyde edinemeyen öğrencilerin becerileri kullanmalarında da sorunlar yaşayabilme olasılığı söz konusudur. Ancak kazanımların bir, iki ve üçüncü sınıf öğrencilerine genel olarak orta düzeyde verilebildiği görülmektedir. Okulların fiziksel yetersizlikleri, ders kitaplarından kaynaklanan sorunlar, sınıfların kalabalık olması gibi sorunlar bu durumun nedenleri olarak görülebilir. Tuncer'in (2009) üçüncü sınıf hayat bilgisi öğretim programı kazanım ve becerilerinin ne derece gerçekleştiğini incelediği araştırmasının sonuçları da bu çalışmanın bulgularını destekler niteliktedir. Ayrıca Şeref'in (2008) araştırmasında da hayat bilgisi dersi kazanımlarının gerçekleşme düzeyinin düşük olduğu ve bu durumu bağımsız-birleştirilmiş sınıflarda eğitim ile öğretmenin mesleki kıdeminin etkilediği belirtilmektedir.

Hayat bilgisi öğretim program bazı kazanımlarının her sınıf düzeyinde çok düşük oranda kazandırıldığı görülmektedir. Bu durumun, hayat bilgisi programının ve ders kitaplarının hazırlanmasında çevresel koşulların göz ardı edilmesine bağlı olabileceği düşünülmektedir. Hayat bilgisi öğretiminde çocuğu, okulu ve çevreyi önemseyen Baymur (1954, s.15) ders kitaplarına karşı çıkmaktadır. Nitekim hayat bilgisi öğretiminin yerelleşmesi ile ilgili araştırma yapan Hızlı Alkan'ın (2016) görüşme yaptığı on sınıf öğretmeninden dokuzu programın yerelleşmesi gerektiğini vurgulayarak öğrencilerin farklı ihtiyaçları, içeriğin anlaşılır olması ve bireysel farklılıkların dikkate alınması gibi konularda yerel öğretim programlarının etkili olacağ 1 düşüncesi hâkim olduğu sonucuna ulaşmıştır. Karaman'ın (2019) da hayat bilgisi konularının ülkenin bölgesel farklılıkları dikkate alınmadan hazırlandığından öğretmenler tarafından eleştirildiği bulgusu da bu yöndedir. Ayrıca öğrencilerin kazanımlara ulaşmasında en önemli etmenin kendi özellikleri olduğu (Öztürk, 2015) dikkate alındığında program hazırlanırken öğrenci farklılığı ve hazırbulunuşluğunun da göz önünde bulundurulmadığı (Öztürk ve Kalafatçı, 2016; Türkyılmaz, 2011; Yıldız, 2009) söylenebilir. 
Altun ve Güler'in (2020) hayat bilgisi dersine yönelik yaptığı araştırmaya göre program çerçevesinde hazırlanan ders kitabındaki örneklerin günlük yaşamla benzeşmediği, programdaki kazanımların bazılarının soyut olduğu, bu kazanımların gerçek yaşama aktarımı zor olduğu ve yenilenen bu programın köy çocuklarına uygun olarak düzenlenmediği belirtilmektedir. Ayrıca Yıldız (2009) birleştirilmiş sınıflarda öğretim yapan öğretmenlerle yaptığı çalışmada hayat bilgisi dersinin çevre olanakları, zaman, araç-gereçlerin ve fiziki koşulları yetersizliği, gelişim özellikleri farklı öğrencilerin bir arada olması, köylerde sağlık, ulaşım ve iletişim sorunlarının yaşanması gibi pek çok sorundan dolayı öğrencilerin beceri ve kazanımlara ulaşamadığı sonucuna ulaşmıştır. Özetle; hayat bilgisi dersi öğretim programının kazanmalarının tüm öğrencilere kazandırılamadığı bunların alanyazındaki araştırmalar çerçevesinde programın merkezi olarak hazırlanması, okulların fiziki ve çevresel koşulları ile materyal eksikliği ve zaman yetersizliğinden kaynaklı olduğu söylenebilir. Bu sonuçlara göre:

- 2018 hayat bilgisi öğretim programında yalnızca birinci sınıfta iki kazanım ile yer verilen "kişisel bakım" becerisinin iki ve üçüncü sınıfta da kazandırılmaya devam edilmesi davranışların pekişmesi ve sürekliliği açısından uygun olabilir.

- 2018 hayat bilgisi öğretim programında bir, iki veya üçüncü sınıfta kazanımları bulunmayan; ancak program kapsamında belirtilen "Karar verme", "Kariyer bilinci geliştirme", "Özyönetim" becerilerine her sınıf seviyesinde yer verilmesi çocuğun benlik gelişimi destekleyecektir.

- Üç sınıf düzeyinde de öğrencilerin "düşük" düzeyde edindikleri düşünülen kazanımların kazandırılamama nedenlerini ayrıntılı olarak ortaya koyabilmek amacıyla farklı okul ortamlarında yerinde gözlem ve görüşmelerle yapılacak araştırmalar derinlikli veriler sunabilecektir.

- Hayat bilgisi öğretim programı kazanımlarının genel olarak orta düzeyde kazandırıldığı sonucu göz önüne alındığında tüm öğrencilerin kazanımları yüksek düzeyde gerçekleştirememelerinin nedenleri ve becerileri yüksek düzeyde kazandıracak koşulların araştırılması bu yönde geliştirilecek stratejiler, ayrılacak kaynaklar ve alınacak önlemler açısından önemli katkılar sağlayacaktır.

\section{KAYNAKÇA}

Altun, T., ve Güler, T. (2020). Sınıf öğretmenlerinin yenilenen hayat bilgisi programı hakkındaki görüşlerinin incelenmesi. YYÜ Eğitim Fakültesi Dergisi (YYU Journal of Education Faculty), 17(1), 54-78.

Aslan, R. (2007). Öğretmen görüşlerine göre ilköğretim birinci basamaktaki ögrrencilerin temel bilgi, beceri ve değerleri kazanma düzeyleri. (Yayınlanmamış Yüksek Lisans Tezi) Anadolu Üniversitesi Eğitim Bilimleri Enstitüsü, Eskişehir.

Aydın, M. Y. (2009). Sorun çözme becerisi ile yaratıcılık arasındaki ilişkinin incelenmesi. (Yayınlanmamış Doktora Tezi) Ankara Üniversitesi Eğitim Bilimleri Enstitüsü, Ankara.

Baymur, F. (1954). Hayat bilgisi dersleri. İstanbul: Maarif Yayınları.

Baysal, Z. N. (2006). Hayat Bilgisi: toplumsal ve doğal yaşama bütüncül bir bakış. C. Öztürk (Ed.). Hayat Bilgisi ve sosyal bilgiler öğretimi içinde (s. 2-17). Ankara: Pegem Akademi Yayınları Yayıncılık.

Bee, H.ve Boyd, D. (2009). Çocuk gelişim psikolojisi. (O. Gündüz, Çev.). İstanbul: Kaknüs Yayınları.

Binbaşıoğlu, C. (2003). Hayat bilgisi öğretimi. Ankara: Nobel Yayın ve Dağıtım. 
Bowen, G. A. (2009). Document analysis as a qualitative research method. Qualitative Research Journal, 9(2), 27-40.

Christensen, L. B., Johnson, R. B. ve Turner, L. A. (2015). Araştırma yöntemleri desen ve analiz (Çev. Ed. A. Aypay). Ankara: Anı Yayınları.

Conger, D. S. ve Mullen, D. (1981). Life skills. International Journal for the Advancement of Counselling, 4, 305-319.

Dange,J. K. (2016) Life skills: A research based Model. University news, 54(48), 67-73.

Doğanay, A. (2006). Etkin vatandaşlık için düşünme becerilerinin öğretimi. C. Öztürk (Ed.). Hayat bilgisi ve sosyal bilgiler ögretimi içinden (s. 179-218) Ankara: Pegem Akademi Yayınları.

Ekmen, M. ve Demir, M. K. (2019). Hayat bilgisi öğretim programı kazanımlarının öğretmen görüşlerine göre incelenmesi. Jass Studies- The Journal of Academic Social Science Studies, 77(K1ş), 35-57.

Erbil, B. A., ve Doğan, B. (2019). İlkokul hayat bilgisi dersi öğretim programı için öğretmenlerin görüşlerine göre ortaya çıkan ihtiyaçlar. Eğitim Kuram ve Uygulama Araştırmaları Dergisi, 5(1), 14-26.

Gümüş, F. (2017). Gelişim kuramları. Y. K. Haspolat, A. Büyükgebiz, İ. Yolbaş ve S. Erturğrul (Edt.). Çocuklarda ve ergenlerde gelişim içinden (ss. 31-65). Ankara: Orient Yayınları

Hızlı-Alkan, S. (2016). Uygulanan Hayat bilgisi öğretim programı'nın yerelleşmesine yönelik ihtiyaç analizi. (Yayınlanmamış Yüksek Lisans Tezi) Ondokuz Mayıs Üniversitesi Eğitim Bilimleri Enstitüsü, Samsun.

Johnsonn, B. ve Christensen, L. (2014). Eğitim araştırmaları: nicel, nitel ve karma yaklaşımlar. S.B. Demir. (Çev. Ed.). Ankara: Eğiten Kitap.

Karabağ, G. ve İnal, S. (2009). Hayat bilgisi dersinde beceri öğretimi. S. Öğülmüş (Ed.). Illö̈gretim hayat bilgisi ögretimi ve ögretmen el kitabı içinde (s. 267-478). Ankara: Pegem Akademi.

Karabörk, T. (2020). Illkokul 1. sinıf hayat bilgisi dersi öğretim programının ögretmen görüşlerine göre değerlendirilmesi. (Yayınlanmamış Yüksek Lisans Tezi). Çukurova Üniversitesi Sosyal Bilimler Enstitüsü, Adana.

Karagözoğlu, C. ve Kemertaş, İ. (2004). Psikoloji danışma ve rehberlik: eğitimde üçüncü boyut. İstanbul: Birsen Yayınları.

Karaman, P. (2019). Hayat Bilgisi Öğretim Programı'ndaki öğelerin öğretmen görüşlerine göre değerlendirilmesi. Iğdır Üniversitesi Sosyal Bilimler Dergisi, 17, 347-367

Karasar, N. (2011). Bilimsel araştırma yöntemleri. Ankara: Nobel Yayın ve Dağıtım.

Kılıççı, Y. (1992). Okulda ruh sağgl̆ğ. Ankara: Şafak Yayınları.

Kıral, B. (2020). Nitel bir veri analizi yöntemi olarak doküman analizi. Siirt Üniversitesi Sosyal Bilimler Enstitüsü Dergisi, 8(15), 170-189.

Milli Eğitim Bakanlığı [MEB] (2005). Hayat bilgisi öğretim programları (ilkokul 1.2. ve 3. sinuflar). Ankara: Milli Eğitim Bakanlığ 1

MEB. (2009). Illköğretim hayat bilgisi öğretim programı. Ankara: Milli Eğitim Bakanlı̆̆ı

MEB. (2015). Hayat bilgisi öğretim programları (ilkokul 1.2. ve 3. sinıflar). Ankara: Milli Eğitim Bakanlığı. 
MEB. (2017). Hayat bilgisi ögretim programları (ilkokul 1.2. ve 3. sınıflar). Ankara: Milli Eğitim Bakanlığı.

MEB. (2018). Hayat bilgisi öğretim programları (ilkokul 1.2. ve 3. sinıflar). Ankara: Milli Eğitim Bakanlığı.

Miles, B., M. ve Huberman, A., M. (1994). Qualitative data analysis. London: Sage Publishing.

OECD (2016). Beceriler önemlidir: yetişkin becerileri araştırmasının kapsamlı sonuçları. Ankara: Çalışma ve Sosyal Güvenlik Bakanlığı. https://www.oecd.org/skills/piaac/Skills-Matter-Turkey-Turkish-version.pdf sayfasından erişilmiştir.

Özen, R., ve Sağlam, H. İ. (2010). İlköğretim öğrencilerinin değişim ve sürekliliği algılayışı. Akademik Bakış Dergisi, 22, 1-15.

Özmete, E. (2011). Building life skills for empowerment of young people: A conceptual analysis. Hacettepe Üniversitesi Sosyolojik Araştırmalar e-Dergisi, 28,1-10.

Öztürk, M. K. (2019). Birinci sınıf hayat bilgisi ders kitabının hayat bilgisi dersi öğretim programında yer alan temel beceriler açısından incelenmesi. TURAN-SAM, 11(41), $535-541$.

Öztürk, T. (2015). Öğrencilerin hayat bilgisi dersi öğretim programındaki temel becerileri kazanmalarına yönelik öğretmen görüşleri. Eğitim ve Bilim, 40(181), 271-292.

Öztürk, T., ve Kalafatçı, Ö. (2016). İlkokul hayat bilgisi dersi öğretim programının uygulanabilirliğinin öğretmen görüşlerine göre değerlendirilmesi. Ihlara Eğitim Araştırmaları Dergisi, 1(1), 58-74.

Powell, M.F (1995). A program for life skills training through interdisciplinary group processes. Journal of Group Psychotherapy, Psychodrama, and Sociometry, 38, 23-34.

Sağlam, M., Babayiğit, O., Gökçe, A., ve Yılmaz, Ö. (2019). 2017 yılı hayat bilgisi dersi öğretim programının öğretmen görüşlerine göre değerlendirilmesi. Uluslararası Türk Ĕ̈itim Bilimleri Dergisi, 12, 38-52.

Snow, W. H. (1985). Skills tarining for coping with life changes. L. D. Gilchrist ve S.P. Schinke (Edt.). Preventing social and health problems through life skills training (ss.83- 89). Center for Social Welfare Research, School of Social Work, University of Washington.

Sönmez, V., ve Alacapınar, F. G. (2013). Örneklendirilmiş bilimsel araştırma yöntemleri. Ankara: Anı Yayınları.

Şencan, H. (2005). Sosyal ve davranışsal ölçümlerde geçerlilik ve güvenirlik. Ankara: Seçkin Yayıncilik.

Şeref, A. (2008). III. sınıf yeni hayat bilgisi dersi programı kazanımlarının gerçekleşme düzeyi. (Yüksek Lisans Tezi). Yeditepe Üniversitesi Sosyal Bilimler Enstitüsü, İstanbul.

Tuncer, Ö. (2009). Illkögretim 3. sinıf hayat bilgisi öğretim programının öğretmen görüşlerine göre değerlendirilmesi. (Yayınlanmamış Yüksek Lisans Tezi) Adnan Menderes Üniversitesi Sosyal Bilimler Enstitüsü, Aydın.

Türkiye Sağlık Bakanlığı. (2020). COVID-19 nedir? https://covid19.saglik.gov.tr/TR66300/covid-19-nedir-.html sayfasından erişilmiştir.

Türkyılmaz, A. (2011). Illköğretim hayat bilgisi dersi ögrretim programının öğretmen görüşlerine dayalı olarak değerlendirilmesi: Balıkesir ili örneği. (Yayınlanmamış Yüksek Lisans Tezi) Balıkesir Üniversitesi Sosyal Bilimler Enstitüsü, Balıkesir. 
UNESCO. (1990). Herkes için eğitim dünya beyannamesi ve temel öğrenme ihtiyaçlarının karşılanması için hareket çerçeve. Herkes için Eğitim Konferansı, 5-9 Mart 1990, Jomtien, Tayland.

UNICEF. (2015). Review of the life skills education programme: Maldives. https://www.unicef.org/evaldatabase/files/LSE_Maldives_review_2015.001.pdf sayfasından erişilmiştir.

Ünsal, H. (2018). Yeni hayat bilgisi dersi 1. sınıf öğretim programının uygulanmasına ilişkin sınıf öğretmenlerinin görüşleri. Social Mentality And Researcher Thinkers Journal, 14, 1082-1092

World Health Organization [WHO]. (1997). Life skills education for children and adolescents in schools. Introduction and guidelines to facilitate the development and implementation of life skills programmes. Geneva, Switzerland: World Health Organization.

WHO. (1999). Partners in life skills education- conclusions from a united nations inter-agency meeting. Department Of Mental Health Social Change And Mental Health Cluster World Health Organization.

Yıldırım, A. ve Şimşek, H. (2013). Sosyal bilimlerde nitel araştırma. Ankara: Seçkin Yayınları.

Yıldız, S. Ş. (2009). 2005 hayat bilgisi dersi ögretim programının birleştirilmiş sınıflarda uygulanabilirliğinin ögretmen görüşlerine göre değerlendirilmesi (nitel bir araştırma). (Yayınlanmamış Yüksek Lisans Tezi) Afyon Kocatepe Üniversitesi Sosyal Bilimler Enstitüsü, Afyonkarahisar.

\section{EXTENDED ABSTRACT}

\section{Introduction}

In the 21st century, on the one hand, rapid technological advances that facilitate human life and social transformations related to this; on the other hand, local and global problems such as global warming, unemployment, wars, conflicts, water crises and hunger are witnessed. The need for individuals who will adapt to these transformations quickly and effectively combat the problems they face locally and globally and produce solutions is increasing day by day. Within the scope of this need, there are changes in education programs. The Ministry of National Education (MoNE, 2005) accepts the life studies course, which is created according to the principle of collective education, considering the developmental characteristics of the child, as a lesson that enables the child to learn about himself, the society and the world he lives in. During the process, changes were made in the LSC in order to adapt to the political, economic and social changes. The purpose of the 2018 LSC, where the last change was made, has been explained as "to raise individuals who have basic life skills, who know themselves, who live a healthy and safe life, who absorb the values of the society they live in, who are sensitive to nature and the environment, who research, produce and love their country". In this way, it is aimed to give students basic life skills. As a matter of fact, basic life skills started with the 2004-2005 LSC and were considered as the aim of the programs in the changes made in 2009, 2015 and finally in 2018. Although the distribution of the objectives was made according to the basic life skills in the 2004-2005 and 2009 LSC, the distribution of the objectives was not made according to the basic life skills in the 2015 and 2018 programs. It is hoped that making this distribution will guide the classroom teachers who are the implementers of the program in terms of revealing the relationship between the objectives and the desired skill. In addition, the distribution of the objectives according to the skills and taking the opinions of the classroom teachers about the level of achieving the objectives will provide important data in terms of evaluating the effectiveness of the program. 


\section{Method}

The survey model was used in this study to determine the level of achievement of the objectives of the LSC applied in the 2018-2019 academic year according to the opinions of classroom teachers. The distribution of basic life skills in the 2018 LSC according to the objectives was also examined through document analysis. 113 classroom teachers filled out the first-grade questionnaire, 68 second-grade, and the third-grade questionnaire by 113 classroom teachers. In order to collect the data of the research, "Distribution of Life Skills According to Objectives in the 2018 Life Studies Curriculum" and "Teachers' Views Regarding the Objectives of the Life Studies Curriculum" were used. Descriptive analysis method was used to examine the distribution of first, second and third grade objectives (148) determined for 2018 LSC according to 23 basic life skills specified in the program. The data based on teachers' opinions about the level of achieving the goals of the program's objectives were analysed by descriptive statistics. The questionnaires based on the teachers' opinions about the level of achieving the goals of the objectives were analyzed by descriptive statistics

\section{Results}

When the objectives and basic life skills of the 2018 LSC were compared, it was concluded that 126 gains out of 148 were compatible with the 23 basic life skills specified in the program. It can be said that a total of 22 objectives in the first, second and third grade are not explained by the basic life skills specified in the program. However, 126 objectives are not equally distributed among the 23 basic life skills specified in the program. Some basic life skills are not included at all grade levels.

Of the 53 objectives of the first-class LSC applied in the 2018-2019 academic year, $40 \%$ are gained at high (21 objectives), $47 \%$ at medium ( 25 objectives), $13 \%$ ( 7 objectives) at a "low" level. It was concluded that $18 \%$ of the 50 objectives of the second-grade LSC (9 objectives) were high, 64\% (32 objectives) were gained at medium level and 18\% (9 objectives) were gained at a low level. Of the 43 objectives of the third-grade LSC, $21 \%$ ( 9 objectives) can be gained at a high level, 63\% (27 objectives) can be earned at medium level and 16\% (7 objectives) can be earned at a low level.

In this context, the following suggestions can be made:

- In the 2018 LSC, it may be appropriate to continue to gain the "personal care" skill, which is only included in the first year with two acquisitions, in the second and third years, in terms of reinforcement and continuity of the behaviors.

- Those who do not have first, second and third grade of objectives in the 2018 LSC; However, including the skills of "Decision Making", "Career Awareness", "SelfManagement" at every grade level will support the self-development of the child.

- Considering the result that LSC acquisitions are generally gained at a medium level, the reasons why all students cannot achieve the objectives at a high level should be investigated and conditions should be created to provide skills at a high level. 